\title{
The Study on Magnetic, Optical and Anti Algal Properties of Low-Temperature Calcined Nickel Ferrite Nanoparticles
}

\author{
Praveena M.G. ${ }^{1, *}$, Mohammed E.M. ${ }^{1}$, Viji C. ${ }^{1}$, Shyam Kumar S. ${ }^{2}$
}

Nickel ferrite $\left(\mathrm{NiFe}_{2} \mathrm{O}_{4}\right.$ ) nanoparticles were synthesized using the sol-gel auto combustion method, and the powdered samples were calcined at two temperatures, $100^{\circ} \mathrm{C}$ and $200^{\circ} \mathrm{C}$. The structure of nickel ferrite nanoparticles was determined using X-ray diffraction (XRD) patterns. The nickel ferrite nanoparticle size was calculated using the Debye-Scherrer formula and was found to be $15.53 \mathrm{~nm}$ and $17.14 \mathrm{~nm}$ for $100{ }^{\circ} \mathrm{C}$ and $200{ }^{\circ} \mathrm{C}$. Field Emission Scanning Electron Microscopic (FESEM) analysis reveals that the samples exhibits spherical morphology with crystalline in nature and also shows some agglomeration. The phase formation of nickel ferrite nanoparticles was further confirmed from the energy dispersive $x$-ray (EDAX) spectra which shows strong peaks for the existence of all the elements in it. The work investigates the magnetic properties of the samples and both the samples exhibits ferromagnetic behavior. The optical band gap obtained for the samples are 2.5 and $2.6 \mathrm{eV}$ for $\mathrm{N}_{1}$ and $\mathrm{N}_{2}$ samples. The antimicrobial activity especially the antialgal effect of $\mathrm{NiFe}_{2} \mathrm{O}_{4}$ nanoparticles on freshwater microalgae Chlorella pyrenoidosa in a dosedependent manner is also reported.

\section{Introduction}

The novel properties of nanostructured materials have received much attention in the scientific community. Due to their large surface area, unusual adsorptive properties, surface defects, and high diffusivity, there has been a growing interest in the synthesis of multifunctional metal oxides in recent decades [1-10]. The magnetic ferrite nanoparticles are used for hyperthermia for cancer treatment, ferrofluid, magnetic drug delivery [11-14]. The physical properties of ferrites are tuned by the chemical composition and method of processing. Spinel ferrites are a class of metal oxides generally conveyed by the stoichiometric formula $\mathrm{AFe}_{2} \mathrm{O}_{4}$, where $\mathrm{A}$ is the divalent metal cations such as $\mathrm{Co}, \mathrm{Mg}, \mathrm{Ni}$, and $\mathrm{Zn}$. Nickel ferrite $\left(\mathrm{NiFe}_{2} \mathrm{O}_{4}\right)$ nanoparticle found very much interest among the spinel ferrites due to their multifunctional properties and are widely used for applications like magnetic drug delivery, microwave devices, and magnetic resonance imaging [15-19]. Nickel ferrite nanoparticles have an inverse spinel structure with a face-centered cubic crystal structure. Production of ferrite nanoparticles has increased

'Department of Physics, Maharaja's College, Ernakulam, Kerala 682011, India

2Department of Botany, Maharaja's College, Ernakulam,

Kerala 682011, India

*Corresponding author:

E-mail: pravigvr05@gmail.com

DOI: 10.5185/amlett.2021.091663 in recent years due to their broad range of application in technical and biomedical fields; thus, many nanoparticles may reach the environments internally or externally, where their purpose and behaviour are largely unknown $[\mathbf{2 0 , 2 1}$. Nanoparticles show a different toxicity profile than their bulk counterparts due to their potential to interact more effectively with biological systems due to their nano size and massive surface area [22-27]. In recent years, algae have been widely used in ecological risk assessments to evaluate the impacts of metal, herbicide, and other xenobiotic contamination and bioavailability in aquatic systems. The main reason for their use is their sensitivity to many contaminants at environmentally relevant concentrations [28]. The soft magnetic and n-type semiconducting nickel ferrite can be synthesized by various physical and chemical methods like mechanical mixing, sol-gel, coprecipitation, ceramic method, hydrothermal etc. [29-34]. The ferrites' properties are influenced by microstructure and composition, which are very sensitive to the processing techniques. Reasonable stoichiometric control and synthesize of ultrafine particles with a narrow size distribution with less processing time are the advantage of the sol-gel method [35]. The present research work aims to employ a conventional sol-gel auto combustion method to synthesize the $\mathrm{NiFe}_{2} \mathrm{O}_{4}$ nanoparticles and to check their anti-algal effect. The role of particle size is also investigated by calcining the nanoparticle at different temperature. The antimicrobial property is specifically dependent to the nanoparticles size. This is because they possess greater capability to reach into the cell membrane and they have large surface area particularly in suspension. 


\section{Advanced Materials Letters https://aml.iaamonline.org}

So that the $\mathrm{NiFe}_{2} \mathrm{O}_{4}$ nanoparticles were calcined at two temperatures, $100^{\circ} \mathrm{C}$ and $200^{\circ} \mathrm{C}$, respectively. Characterized the samples using powder X-ray diffraction and FESEM-EDAX, magnetic and optical properties of the samples were investigated. We explore the effect of the nanoparticles for microalgae Chlorella pyrenoidosa. And also investigated the influence of particle size of nickel ferrite nanoparticle on the antialgal efficiency.

\section{Experimental details}

\section{Synthesis of $\mathrm{NiFe}_{2} \mathrm{O}_{4}$ nanoparticle}

For the preparation of nanoparticles, stoichiometric ratios of AR grade Ferric nitrate $\left(\mathrm{Fe}(\mathrm{NO} 3)_{3} .9 \mathrm{H}_{2} \mathrm{O}\right)$ and Nickel nitrate $\left(\mathrm{Ni}\left(\mathrm{NO}_{3}\right)_{2} .6 \mathrm{H}_{2} \mathrm{O}\right)$ were dissolved in a minimum amount of ethylene glycol at room temperature. After that, the solution is heated to $60^{\circ} \mathrm{C}$ to form a wet gel. The gel was then dried at $120^{\circ} \mathrm{C}$ for 2 hours, after which it selfignited to form $\mathrm{NiFe}_{2} \mathrm{O}_{4}$ powder. The combustion of the gel can be thought of as a thermally induced redox reaction in which ethylene glycol acts as a reducing agent and the nitrate ion acts as an oxidant. The nitrate ion provides an in situ oxidizing atmosphere for the decomposition of the organic component. The obtained product was then finely ground. The powder was separated into two parts and calcined at two different temperatures $100{ }^{\circ} \mathrm{C}$ and $200{ }^{\circ} \mathrm{C}$, for 2 hours in a muffle furnace.

\section{Culturing of the algae}

Experiments were carried out at the Marine Botany Laboratory, School of Marine Sciences, CUSAT, with freshwater green algae belonging to the division Chlorophyta, Chlorella pyrenoidosa. The exponentially growing Chlorella pyrenoidosa with a cell density of $6 \times 104$ cells $/ \mathrm{ml}$ was taken $15 \mathrm{ml}$, and it was inoculated into a $150 \mathrm{ml}$ Walnes medium contained in a $250 \mathrm{ml}$ Erlenmeyer flasks in the absence and presence of the test substance. The culture without the content of nickel ferrite was taken as the control. $\mathrm{NiFe}_{2} \mathrm{O}_{4}$ calcined at different temperatures were added to the test culture. The cultures were incubated at the optimum conditions of growth for eight days. The incubation of the culture was done using two cold white fluorescent light of 1250 lux each for a light/dark period of 12:12 hours. Cultures were maintained at room temperature $\left(30 \pm 2{ }^{\circ} \mathrm{C}\right)$.

\section{Algal growth inhibition study}

The algal growth inhibition analysis was carried out by measuring algal chlorophyll content and cell count every 48 hours. Algal cell density was measured using a Neubauer Hemocytometer in cell numbers (algal cell/ml). Cell count investigated the effect of nickel ferrite annealing temperature on Chlorophyll for 8 days with a regular interval of $48 \mathrm{hrs}$. The specific growth rate was calculated using the below equation (1) [36].

$$
\mu=\frac{L_{n} N_{t}-L_{n} N_{0}}{t_{n}}
$$

$\mathrm{N}_{\mathrm{t}}$ is the measured final cell density, $\mathrm{N}_{0}$ the initial cell density ( $6 \times 104$ cells $/ \mathrm{ml}), t_{n}$ is the incubation period (in days).

\section{Characterization of $\mathrm{NiFe}_{2} \mathrm{O}_{4}$ nanoparticles.}

The phase composition and crystal structure $\mathrm{NiFe}_{2} \mathrm{O}_{4}$ nanoparticles were identified using the XRD (X-Ray Diffraction) analysis at room temperature for a range of 2 theta values $20^{\circ}$ to $80^{\circ}$ on using Rigaku Mini Flex 600 equipped with $\mathrm{Cu} \mathrm{K} \alpha$ radiation $(\lambda=1.5406 \AA)$. The prepared nanoparticles' structural morphology was studied using the FESEM (Field Emission Scanning Electron Microscopy) analysis. FESEM analysis for the $\mathrm{NiFe}_{2} \mathrm{O}_{4}$ was recorded using a ZEISS sigma microscope attached with EDAX set up. The presence of various elements in the samples was investigated from the EDAX spectrum. The optical properties exhibited by the $\mathrm{NiFe}_{2} \mathrm{O}_{4}$ nanoparticles was analyzed from UV-Vis (Diffusion Reflectance Spectrum) spectrum. The prepared nanoparticles' magnetic properties were studied from the VSM (Vibrating Sample Magnetometer) analysis result. The powder samples were used for the analysis.

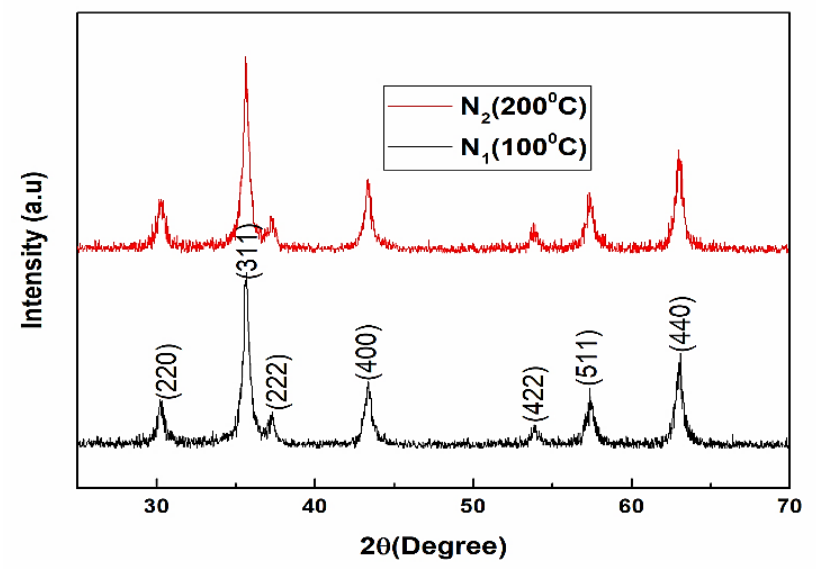

Fig. 1. XRD diffractogram for $\mathrm{NiFe}_{2} \mathrm{O}_{4}$ at $100^{\circ} \mathrm{C}\left(\mathrm{N}_{1}\right)$ and $\mathrm{NiFe}_{2} \mathrm{O}_{4}$ at $200^{\circ} \mathrm{C}\left(\mathrm{N}_{2}\right)$

\section{Results and discussion}

\section{$X$-Ray diffraction analysis}

The diffraction pattern reveals the cubic spinel structure of the prepared nickel ferrite nanoparticles. The obtained XRD diffractogram for the nickel ferrite nanoparticles calcined at two temperature $\left(100^{\circ} \mathrm{C}\right.$ and $\left.200^{\circ} \mathrm{C}\right)$ is shown in Fig. 1. Sharp well defined and intense peaks were observed for the synthesized samples. No impurity peaks confirm a single-phase nickel ferrite nanoparticles formation, thereby ensuring the synthesized samples' phase purity. The diffraction peak pattern was indexed using the standard JCPDS card no-074-2081. The mean crystallite sizes for the samples were calculated from the X-ray line broadening using the Debye-Scherer equation given in equation (2).

$$
\mathrm{D}=(0.9 * \lambda) /(\beta \cos \theta)
$$




\section{Advanced \\ Materials Letters \\ https://aml.iaamonline.org}

where $\lambda$ represents the $X$-ray wavelength's wavelength, $\beta$ is the full-width half maximum (FWHM) of the diffraction pattern, and $\theta$ is Bragg's angle. The average particle size obtained for the two prepared nickel ferrite nanoparticles is tabulated in Table 1. The average nanoparticle size is 15.53 $\mathrm{nm}$ and $17.14 \mathrm{~nm}$ for $100^{\circ} \mathrm{C}$ and $200^{\circ} \mathrm{C}$ calcined nickel ferrite. To compare the value of the lattice parameters obtained for the nickel ferrite sample calcined at two different temperature, the lattice parameter a was also calculated using the relation (3).

$$
\mathrm{a}=\mathrm{d}_{(\mathrm{hkl})} /\left(\mathrm{h}^{2}+\mathrm{k}^{2}+\mathrm{l}^{2}\right)^{1 / 2}
$$

The lattice constant is almost constant and shows only minor variations with sintering temperature, as shown in the table. However, the size of the nanoparticles increases with calcination temperature. The prepared nickel ferrite samples with a cubic structure have Fd-3m space group.

Table 1. List of particle size and constant lattice values obtained for $\mathrm{NiFe}_{2} \mathrm{O}_{4}$ at $100^{\circ} \mathrm{C}\left(\mathrm{N}_{1}\right)$ and $\mathrm{NiFe}_{2} \mathrm{O}_{4}$ at $200^{\circ} \mathrm{C}\left(\mathrm{N}_{2}\right)$.

\begin{tabular}{llllll}
\hline $\begin{array}{l}\mathbf{2 \theta} \\
\left(\mathbf{N}_{\mathbf{1}}\right)\end{array}$ & $\begin{array}{l}\text { Particle } \\
\text { size } \\
\mathbf{D}(\mathbf{n m})\end{array}$ & $\begin{array}{l}\text { Lattice } \\
\text { Parameter } \\
\mathbf{a}(\mathbf{\AA})\end{array}$ & $\begin{array}{l}\mathbf{2 \theta} \\
\left(\mathbf{N}_{\mathbf{2}}\right)\end{array}$ & $\begin{array}{l}\text { Particle } \\
\text { size } \\
\mathbf{D}(\mathbf{n m})\end{array}$ & $\begin{array}{l}\text { Lattice } \\
\text { Parameter } \\
\mathbf{a}(\mathbf{\AA})\end{array}$ \\
\hline 30.25 & 16.8077 & 8.3565 & 30.22 & 19.1516 & 8.3383 \\
35.64 & 14.1544 & 8.3547 & 35.69 & 16.0621 & 8.3411 \\
43.38 & 16.4544 & 8.4342 & 43.36 & 18.2036 & 8.3434 \\
\hline
\end{tabular}

\section{Field emission scanning electron microscopy analysis}

The morphology of the prepared $\mathrm{NiFe}_{2} \mathrm{O}_{4}$ nanoparticles was analyzed from the FESEM micrographs, shown in Fig. 2. and Fig. 4. FESEM micrograph illustrates the micrometrical aggregation of tiny spherical nanoparticles. The presence of high-density agglomeration suggests the presence of pore-free crystallites on the surface. The nanoparticles agglomerate and expand into larger assemblies due to their high surface energies.
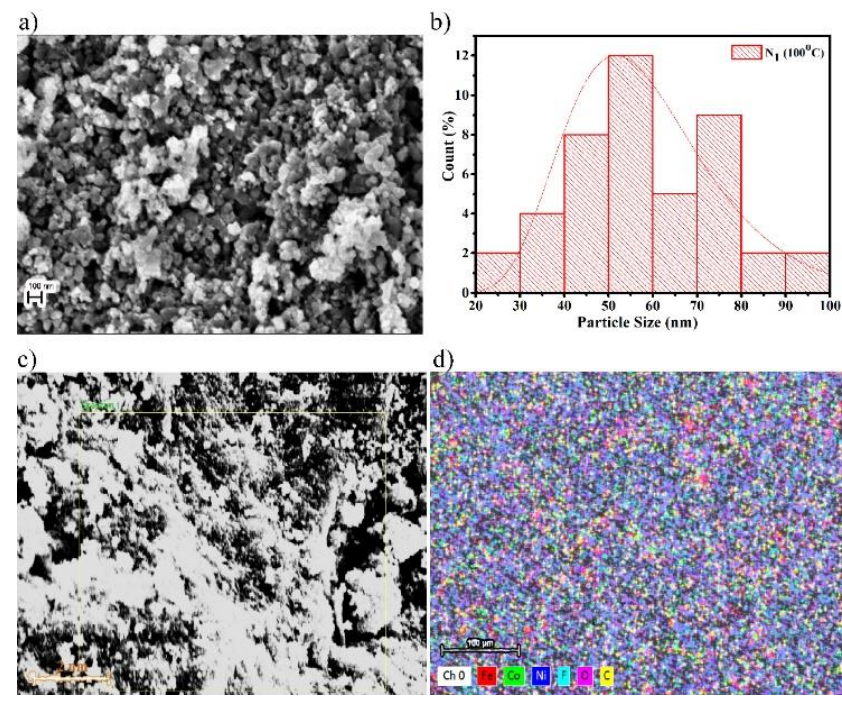

Fig. 2. (a) and (b) represents the FESEM micrograph and histogram of particle distribution (c) and (d) corresponds to the EDAX image mapping for $\mathrm{NiFe}_{2} \mathrm{O}_{4}$ at $100{ }^{\circ} \mathrm{C}\left(\mathrm{N}_{1}\right)$. (a)

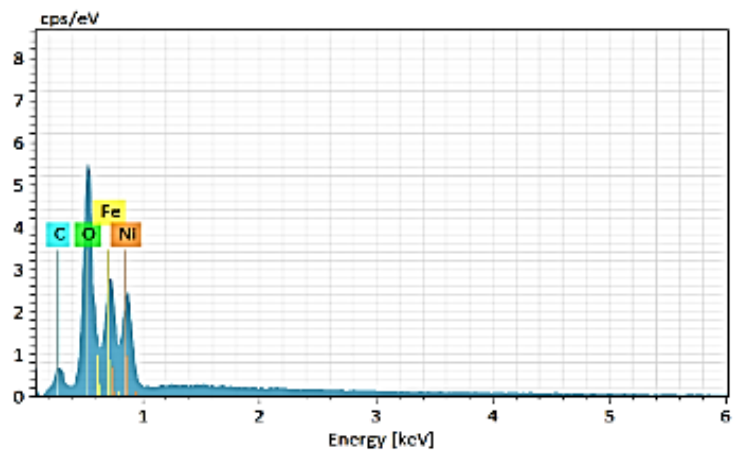

(b)

\begin{tabular}{|c|c|c|c|c|c|c|c|}
\hline Element & $\begin{array}{l}\text { At. } \\
\text { No. }\end{array}$ & Netto & $\begin{array}{c}\text { Mass } \\
{[\%]}\end{array}$ & $\begin{array}{c}\text { Mass } \\
\text { Norm. } \\
{[\%]}\end{array}$ & $\begin{array}{c}\text { Atom } \\
{[\%]}\end{array}$ & $\begin{array}{c}\text { abs. error } \\
{[\%]} \\
\text { (1sigma) }\end{array}$ & $\begin{array}{c}\text { rel. error } \\
{[\%]} \\
(1 \text { sigma })\end{array}$ \\
\hline$\overline{\text { Carbon }}$ & 6 & 3355 & 7.78 & 7.01 & 16.78 & 1.34 & 17.23 \\
\hline Oxygen & 8 & 29553 & 31.07 & 27.98 & 50.31 & 3.85 & 12.41 \\
\hline Iron & 26 & 4471 & 46.06 & 41.47 & 21.37 & 2.25 & 4.89 \\
\hline \multirow[t]{2}{*}{ Nickel } & 28 & 15375 & 26.15 & 23.54 & 11.54 & 3.48 & 13.32 \\
\hline & & Sum & 111.06 & 100.00 & 100.00 & & \\
\hline
\end{tabular}

Fig. 3. (a) The EDAX spectrum and (b) is the table showing the atomic weight percentage of each element in the $\mathrm{NiFe}_{2} \mathrm{O}_{4}$ at $100{ }^{\circ} \mathrm{C}\left(\mathrm{N}_{1}\right)$ sample.
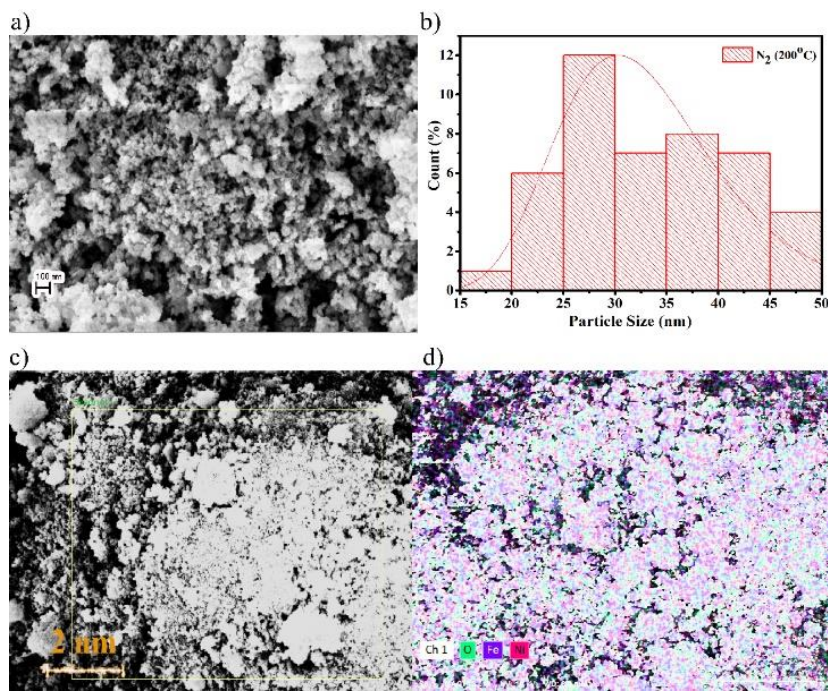

Fig. 4. (a) and (b) represents the FESEM micrograph and histogram of particle distribution c) and d) corresponds to the EDAX image mapping for $\mathrm{NiFe}_{2} \mathrm{O}_{4}$ at $200{ }^{\circ} \mathrm{C}\left(\mathrm{N}_{2}\right)$

EDAX analysis was used to look at the various elements present in the prepared samples. In both the samples, the spectrum displays strong peaks corresponding to $\mathrm{O}, \mathrm{Fe}$, and $\mathrm{Ni}$, which implies the samples' phase purity. The atomic weight percentage of each element in the nickel ferrite sample calcined at $100{ }^{\circ} \mathrm{C}$ is given in Fig. 3. and Fig. 5. The homogenous distribution of iron, nickel and oxygen in the ferrite nanoparticles is confirmed from EDAX mapping, and it is shown in Fig. 2(d) and Fig. 4(d). The stoichiometric formula of nickel ferrite requires $\mathrm{Ni}, \mathrm{Fe}$, and O's ratio as 1:2:4. The presence of carbon in the spectrum is due to the carbon coating over the grid to place the sample for the measurements. We could see that prepared samples meet the requirements or the expected composition and 
Advanced Materials Letters https://aml.iaamonline.org

elements from the results. Hence, the chemical composition requirement of the $\mathrm{NiFe}_{2} \mathrm{O}_{4}$ is in good agreement with the results obtained by our study.

(a)

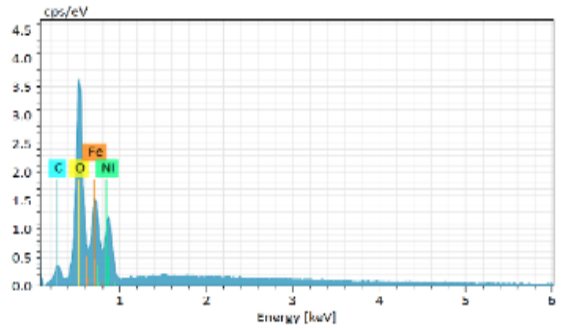

(b)

Spectrum 1

\begin{tabular}{lrrrrrrr}
\hline Element & $\begin{array}{c}\text { At. } \\
\text { No. }\end{array}$ & Netto & $\begin{array}{c}\text { Mass } \\
{[\%]}\end{array}$ & $\begin{array}{c}\text { Mass } \\
\text { Norm. } \\
{[\%]}\end{array}$ & $\begin{array}{c}\text { Atom } \\
{[\%]}\end{array}$ & $\begin{array}{c}\text { abs. error rel. error } \\
{[\%]} \\
\text { (1sigma) }\end{array}$ & $\begin{array}{c}\text { [\%] } \\
\text { (1 sigma) }\end{array}$ \\
\hline Carbon & 6 & 1619 & 3.66 & 4.66 & 12.21 & 0.76 & 20.62 \\
Oxygen & 8 & 19653 & 19.30 & 24.54 & 48.32 & 2.51 & 12.98 \\
Iron & 26 & 4286 & 42.32 & 53.81 & 30.35 & 2.08 & 4.91 \\
Nickel & 28 & 7537 & 13.36 & 16.99 & 9.12 & 1.98 & 14.79 \\
\hline \multicolumn{2}{c}{ Sum } & $\mathbf{7 8 . 6 6}$ & $\mathbf{1 0 0 . 0 0}$ & $\mathbf{1 0 0 . 0 0}$ & & \\
\hline
\end{tabular}

Fig. 5. (a) The EDAX spectrum and (b) is the table showing the atomic weight percentage of each element in the $\mathrm{NiFe}_{2} \mathrm{O}_{4}$ at $200{ }^{\circ} \mathrm{C}\left(\mathrm{N}_{2}\right)$ sample.

\section{The magnetic properties analysis}

The synthesized nickel ferrite nanoparticles' magnetic characteristics are studied using the VSM measurements with an external applied magnetic field ranging from - 25 $\mathrm{kOe}$ to $+25 \mathrm{kOe}$. The room temperature magnetic hysteresis loop is shown in Fig. 6. The values of magnetic parameters remanence, coercivity, saturation magnetization and magnetic squareness ratio were noted and listed in Table 2. It could be noted that a soft ferromagnetic nature of nickel ferrite was observed from the M-H loop. The magnetic parameters show a decreasing value with an increase in calcination temperature and connected to the increasing grain size. The decrease in the value of coercivity for the prepared nickel ferrite nanoparticles compared bulk can be interpreted by considering the reduced porosity and increased crystallite size. The nanoparticle's saturation magnetization value is in the range of 41-45 emu/g, which is small compared to bulk nickel ferrite $(55 \mathrm{emu} / \mathrm{g})$ [37-39]. The magnetic squareness ratio value at and above 0.5 corresponds to materials having single magnetic domain size and the value below 0.5 implies to materials with the multi domain structure. So according to that the prepared nickel ferrite nanoparticles exhibits multi domain structure with orientation changes with the applied magnetic field facilitated by the movement of domain walls [40-43].

Table 2. The variation of magnetic order parameters for the nickel ferrite nanoparticles.

\begin{tabular}{cccccc}
\hline $\begin{array}{c}\text { Calcination } \\
\text { temperature } \\
\left({ }^{\circ} \mathrm{C}\right)\end{array}$ & $\begin{array}{c}\text { Size of } \\
\text { nickel } \\
\text { ferrite } \\
\text { nanoparti } \\
\text { cle }(\mathrm{nm})\end{array}$ & $\begin{array}{c}\text { Remanence } \\
\mathrm{M}_{\mathrm{r}} \\
(\mathrm{emu} / \mathrm{g})\end{array}$ & $\begin{array}{c}\text { Saturation } \\
\text { Magnetiza } \\
\text { tion } \\
\mathrm{M}_{\mathrm{s}}\end{array}$ & $\begin{array}{c}\text { Coercivity } \\
\mathrm{H}_{\mathrm{c}} \\
(\mathrm{Oe})\end{array}$ & $\begin{array}{c}\text { Square } \\
\text { ness } \\
\text { Ratio } \\
\left(\mathrm{M}_{\mathrm{r}} / \mathrm{M}_{\mathrm{s}}\right)\end{array}$ \\
\hline 100 & 15.53 & 6.39 & 41.8 & 101 & 0.152 \\
200 & 17.14 & 8.6 & 44.7 & 151 & 0.192 \\
\hline
\end{tabular}

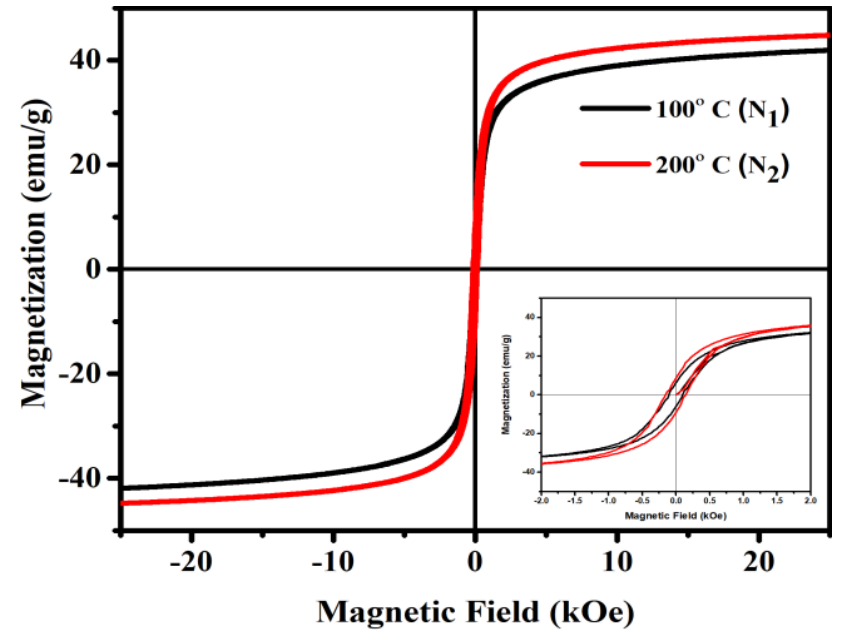

Fig. 6. The M-H hysteresis loop showing the variation of magnetization value with applied magnetic field for the synthesized $\mathrm{NiFe}_{2} \mathrm{O}_{4}$ at $100^{\circ} \mathrm{C}$ $\left(\mathrm{N}_{1}\right)$ and $\mathrm{NiFe}_{2} \mathrm{O}_{4}$ at $200^{\circ} \mathrm{C}\left(\mathrm{N}_{2}\right)$.
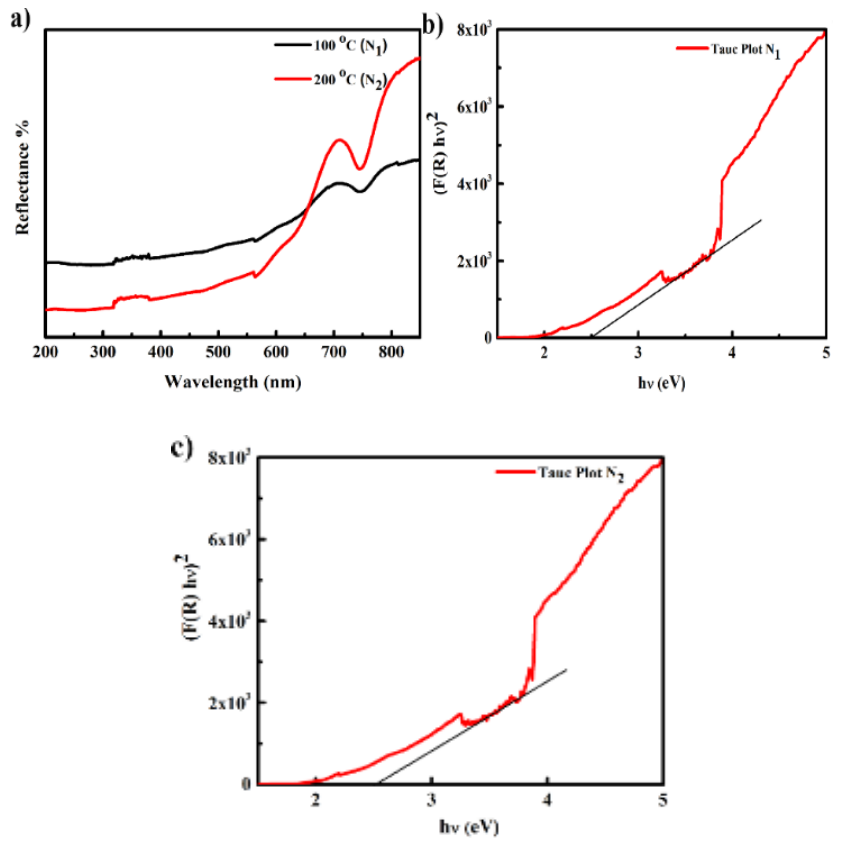

Fig. 7. UV- Vis DRS spectra of a) $\mathrm{NiFe}_{2} \mathrm{O}_{4}$ at $100^{\circ} \mathrm{C}\left(\mathrm{N}_{1}\right)$ and $\mathrm{NiFe}_{2} \mathrm{O}_{4}$ at $200^{\circ} \mathrm{C}\left(\mathrm{N}_{2}\right)$. b) and c) Tau'c Plot for $\mathrm{N}_{1}$ and $\mathrm{N}_{2}$.

\section{Linear optical property analysis}

The optical properties of the prepared nanoparticles were explored using UV-vis diffuse reflectance spectroscopy. Fig. 7(a) displays the obtained reflectance spectra of Kebelka Munk function vs photon energy (hv). To determine the optical band gap, the Tauc plot is used and is shown in Fig. 7(b) and Fig. 7(c). The Kebelka Munk function using the reflectance data was used for the calculation of bandgap energy.

$$
\mathrm{F}(\mathrm{R})=\frac{(1-R)^{2}}{2 R}
$$

where $F(R)$ is the Kubelka - Munk function and $R$ is the reflectance value. $(\mathrm{F}(\mathrm{R}) \mathrm{h} v)^{2}$ versus $\mathrm{hv}$ is plotted by 


\section{Advanced Materials Letters https://aml.iaamonline.org}

considering the direct transition model for the nickel ferrite nanoparticles. The nickel ferrite sample's calculated band gap energy value is 2.5 and $2.6 \mathrm{eV}$ for $\mathrm{N}_{1}$ and $\mathrm{N}_{2}$ samples, respectively. The nanoparticles' bandgap energy can be affected by the calcination temperature and crystallite size [44-48]. So that a slight variation is observed in the bandgap energy value is observed.

\section{Photosynthesis pigment analysis}

The effect of nickel ferrite nanoparticles on pigment content as a measure of algal growth was investigated. The Fig. 8(a) and Fig. 8(b) shows the variation of growth of Chlorophyll-a for a time gap of $48 \mathrm{hrs}$ for the control (without nanoparticles) and different calcination temperature of $\mathrm{NiFe}_{2} \mathrm{O}_{4}$.

(a)

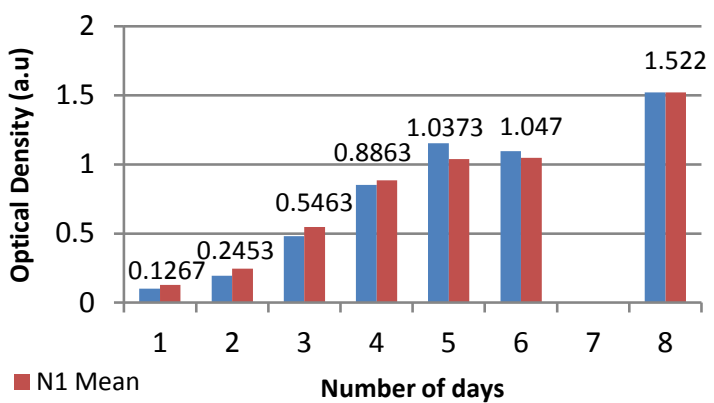

(b)

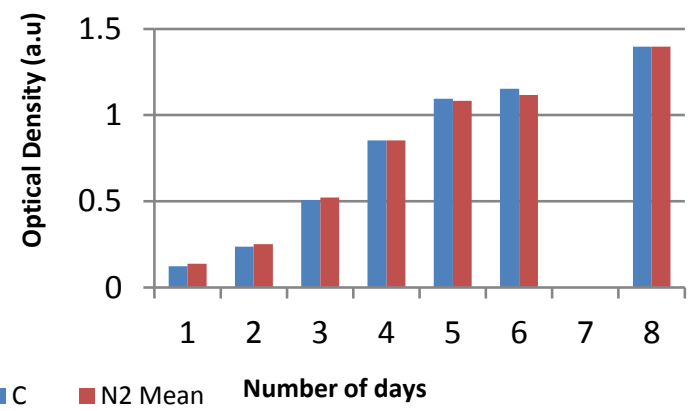

Fig. 8. (a) and (b) represents the variation of Chlorophyll-a growth for a time gap of $48 \mathrm{hrs}$ for the control (without nanoparticles) and $\mathrm{NiFe}_{2} \mathrm{O}_{4}$ calcined at two temperatures.

Table 3. The growth rate observed for control and the nickel ferrite nanoparticles.

\begin{tabular}{cc}
\hline Sample code & Growth rate \\
\hline $\mathrm{C}($ control $)$ & 0.078048 \\
$\mathrm{~N}_{1}$ & 0.077117 \\
$\mathrm{~N}_{2}$ & 0.071808 \\
\hline
\end{tabular}

Chlorophyll a content shown a significant reduction in growth with exposure to $\mathrm{NiFe}_{2} \mathrm{O}_{4}$ nanoparticles in contrast to the control (untreated) value, which is given in Table 3. The increase in the calcination temperature of nanoparticles shows an impact on the growth rate of the algae Chlorophyll-a, and it gets decreased. The cell density decreases as the calcination temperature rises, indicating that the calcination temperature of nickel ferrite has an inhibitory effect. The abnormal behaviour of nickel ferrite on Chlorella pyrenoidosa may be due to the fact that, while nickel and iron are important micronutrients for algal metabolism, they can also be toxic and inhibit metabolic processes when used in amounts higher than the optimal level [49-53]. This observed variability in algal toxicity may be due to a variety of factors. Abiotic factors such as the composition of culture and test medium may have a major effect on the organism's tolerance level [54].

\section{Conclusion}

This study focused on the dielectric properties and antialgal efficiency of the prepared nickel ferrite nanoparticles towards the green algae Chlorella pyrenoidosa for the first time. Nickel ferrite $\left(\mathrm{NiFe}_{2} \mathrm{O}_{4}\right)$ nanoparticles with two different particle size were synthesized by the sol-gel auto combustion method. The phase purity and cubic spinel structure of nickel ferrite were established from the XRD pattern. The FESEM analysis of the nanoparticles reveals spherical-shaped particle with some agglomerations. The elemental composition of the samples was verified from EDAX analysis. The optical band gap of 2.5 and $2.6 \mathrm{eV}$ for $\mathrm{N}_{1}$ and $\mathrm{N}_{2}$ samples was calculated from UV measurement. The nanoparticles behave like soft ferrites with saturation magnetization in the range of $41-45 \mathrm{emu} / \mathrm{g}$. Our results indicate that $\mathrm{NiFe}_{2} \mathrm{O}_{4}$ calcined at $200^{\circ} \mathrm{C}$ shows a stimulatory effect on Chlorella pyrenoidosa, but the sample calcined at $100^{\circ} \mathrm{C}$ inhibits the growth. This dual influence of calcination temperature of nickel ferrite on the algal growth can be interpreted as when the usage of nickel ferrite nanoparticles in amounts higher than the optimal level can be toxic and inhibit metabolic processes.

\section{Acknowledgements}

The authors gratefully acknowledge the Kerala State Council for Science, Technology and Environment (KSCSTE), Kerala, India, for the financial support. We thank the Head of the Department of Physics and the Principal, Maharaja's College, Ernakulam. The authors thank Dr Swapna S. Nair, Central University of Kerala, Kasaragod, for the VSM measurements.

\section{Keywords}

Chlorella pyrenoidosa, nickel ferrite, magnetic characteristics, optical band gap.

Received: 26 March 2021

Revised: 8 May 2021

Accepted: 29 May 2021

\section{References}

1. Almessiere, M.A.; Slimani, Y.; Güner, S.; Baykal, A.: Ercan, I.; J. Rare Earths., 2019, 37, 871.

2. Korkmaz, A. D.; Güner, S.; Slimani, Y.; Gungunes, H.; Md Amir; Manikandan, A.; Baykal, A.; J. Supercond. Nov. Magn., 2019, 32, 1057.

3. Almessiere, Y.S.M.A.; Tashkandi, S.G.N.A.; Sarac, A.B.M.F Ercan, M.N.I.; J. Mater. Sci. Mater. Electron., 2019, 30, 9143.

4. Almessiere, M.A.; Ünal, B.; Slimani, Y.; Korkmaz, A.D.; Baykal, A.; Ercan, I.; La, Y.; Results Phys., 2019, 15, 102755. 
5. Nawaz, M.; Almessiere, M.A.; Almofty, S.A.; Gungunes, C.D.; Slimani, Y.; Baykal, A.; J. Photochem. Photobiol. B Biol., 2019 196, 111506.

6. Almessiere; Munirah; Yassine Slimani; Murat Sertkol; Muhammed Nawaz; Ali Sadaqat; Abdulhadi Baykal; Ismail Ercan; Bekir Ozçelik; J. Nanomater., 2019, 9, 430.

7. Yasin, G.; Junaid, M.; Uzair, M.; Abubaker, M.; Qamar, W.; Arif, M.; Mehtab, T.; Anh, T.; Slimani, Y.; Tabish, M.; Ali, D.; Zuo, Y.; Diam. Relat. Mater., 2020, 104, 107763.

8. Akhtar, S.; Rehman, S.; Almessiere, M.A.; Khan, F.A.; $J$ Nanomater., 2019, 11, 1635.

9. Tombuloglu, H.; Slimani, Y.; Tombuloglu, G.; Almessiere, M.; Environ. Nanotechnology, Monit. Manag., 2019, 11, 100223.

10. Manikandan, A.; Yogasundari, M.; Thanrasu, K.; Dinesh, A.; Raja, K.K.; Slimani, Y.; Jaganathan, S.K.; Srinivasan, R.; Baykal, A.; Phys. E Low-Dimensional Syst. Nanostructures., 2020, 124, 114291.

11. Pubby, K.; Meena, S.S.; Yusuf, S.M.; Bindra, S.; J. Magn. Magn. Mater., 2018, 466, 430 .

12. Srinivas, Ch; Tirupanyam, B. V.; Meena, S. S.; Yusuf, S. M.; Seshu Babu, Ch; Ramakrishna, K. S.; Potukuchi, D. M.; Sastry. D. L.; J. Magn. Magn. Mater., 2016, 407, 135

13. Gawas, Satu G.; Sher Singh Meena; Seikh M. Yusuf; Vidhyadatta MS Verenkar; New J. Chem., 2016, 40, 9275

14. Banerjee, A.M.; Pai, M.R.; Meena, S.S.; Tripathi, A.K.; Bharadwaj, S.R.; Int. J. Hydrogen Energy, 2011, 36, 4768.

15. Sundararajan, M.; Kennedy, L.J.; Aruldoss, U.; Khadeer, S.; Vijaya, J.J.; Dunn, S.; Mater. Sci. Semicond. Process, 2015, 40, 1.

16. Sundararajan, M.; Kennedy, L.J.; Vijaya, J.J.; Aruldoss, U.; Spectrochim. Acta Part A Mol. Biomol. Spectrosc., 2014, 4, 30.

17. Sundararajan, M.; Sailaja, V.; Kennedy, L.J.; Vijaya, J.; Ceram. Int., 2017, 43, 540

18. Sundararajan, M.; Kennedy, L.J.; Biochem. Pharmacol., 2017, 4, 61.

19. Manikandan, A.; Vijaya, J.J.; Sundararajan, M.; Meganathan, C.; Kennedy, L.J.; Bououdina, M.; Superlattices and Microstruct., 2013, 64, 118.

20. Akhtar, S.; Ercan, I.; Belenli, I.; Ceram. Int., 2019, 45, 6021

21. Ben Salem, M.K.; Slimani, Y.; Hannachi, E.; Ben Azzouz, F.; Ben Salem, M.; Cryogenics (Guildf)., 2018, 89, 53.

22. Slimani, Y.; Unal, B.; Hannachi, E.; Selmi, A.; Almessiere, M.A.; Nawaz, M.; Baykal, A.; Ceram. Int., 2019, 45, 11989.

23. Manikandan, A.; Baykal, A.; Ben, F.; Ceram. Int., 2019, 45, 6828.

24. Seevakan, K.; Manikandan, A.; Devendran, P.; Slimani, Y.; Baykal, A.; Alagesan, T.; J. Magn. Magn. Mater., 2019, 486, 165254

25. Selmi, Y.S.A.; Almessiere, E.H.M.A.; Ercan, M.M.A.B.I.; J. Mater. Sci. Mater. Electron., 2019, 30, 13509.

26. Ozçelik, B.; Ercan, I.; J. Magn. Magn. Mater., 2020, 510, 166933.

27. Yasin, G.; J. Mater. Sci.: Mater. Electron., 2020, 31, 7786

28. Qian, H.; Li, J.; Sun, L.; Chen, W.; Sheng, G.D.; Liu, W.; Fu, Z.; Aquat. Toxicol., 2009, 94, 56.

29. Hannachi, E.; Slimani, Y.; Ben Azzouz, F.; Ekicibil, A.; Ceram. Int., 2018, 44, 18836 .

30. Selmi, Y.S.A.; Almessiere, E.H.M.A.; Ercan, A.B.I.; J. Mater. Sci. Mater. Electron., 2019, 30, 9520.

31. Almessiere, M.A.; Slimani, Y.; Baykal, A.; J. Alloys Compd., 2018, $762,389$.

32. Slimani, Y.; Almessiere, M.A.; Korkmaz, A.D.; Guner, S.; Güngüne, H.; Sertkol, M.; Manikandan, A.; Yildiz, A.; Akhtar, S.; Shirsath, S.E.; Baykal, A.; Ultrason Sonochem., 2019, 59, 104757.

33. Slimani, Y.; Almessiere, M.A.; Sertkol, M.; Shirsath, S.E.; Baykal, A.; Nawaz, M.; Akhtar, S.; Ozcelik, B.; Ercan, I.; Ultrason Sonochem., 2019, 57, 203.

34. Almessiere, Y.S.M.A.; Kurtan, S.G.U.; Shirsath, S.E.; Ercan, A.B.I.; J. Sol-Gel Sci. Technol., 2020, 95, 202.

35. Nalwa, Hari Singh, (Ed.) Nanostructured Materials and Nanotechnology: Concise Edition. Elsevier 2001

36. Muyssen, B.T.A.; Janssen, C.R.; Chemosphere, 2001, 45, 507.

37. Chauhan, L.; Shukla, A.K.; Sreenivas, K.; Ceram. Int., 2015, 41, 8341

38. Ortiz-quin, J.; Pal, U.; Villanueva, M.S.; ACS Omega, 2018, 3, 14986

39. Joshi, S.; Kumar, M.; Chhoker, S.; Srivastava, G.; Jewariya, M.; Singh, V.N.; J. Mol. Struct., 2014, 1076, 55.
40. Dhiwahar, A.T.; Maruthamuthu, S.; Marnadu, R.; Sundararajan, M. Manthrammel, M.A.; Shkir, M.; Sakthivel, P.; Reddy, V.; Reddy, M.; Solid State Sci., 2021, 113, 106542.

41. Baskar, S.; Yuvaraj, S.; Sundararajan, M.; J. Supercond. Nov. Magn., 2020, 33, 3949.

42. Baskar, S.; Partha, Y.S.; Subudhi, S.; Dash, C.S.; J. Chin Chem Soc. 2020, 68, 630

43. Kagdi, A.R.; Solanki, N.P.; Carvalho, F.E.; Meena, S.S.; Pullar, R.C.; Jotania, R.B.; J. Alloys Compd., 2018

44. Kombaiah, K.; Vijaya, J.J.; Kennedy, L.J.; Kaviyarasu, K.; West, S.; Province, W.C.; S. Africa, Mater. Chem. Phys., 2019, 221, 11.

45. Chavan, P.; Phys. Status Solidi (A), 2017, 214, 1700077.

46. Baykal, A.; Ultrason Sonochem., 2019, 58, 104654.

47. Shirsath, S.E.; Ercan, İ; Ozçelik, B.; Ultrason Sonochem, 2019, 58, 104621 .

48. Almessiere, M.A.; Slimani, Y.; Korkmaz, A.D.; Güner, S.; Baykal, A.; Shirsath, S.E.; Ercan, I.; Kögerler, P.; Ultrason Sonochem., 2020, 61, 104836.

49. Li, M.; Hu, C.; Zhu, Q.; Chen, L.; Kong, Z.; Liu, Z.; Chemosphere., 2006, 62, 5656.

50. Tomitaka, A.; Hirukawa, A.; Yamada, T.; Morishita, S. Y Takemura, S.; J. Magn. Magn. Mater., 2009, 321, 1482.

51. Sagadevan, S.; Chowdhury, Z.Z.; Rafique, R.F.; Brunswick, N.; Mater. Res., 2018, 21, 21.

52. Adochite; Cristina; Luminita Andronic; Water J., 2021, 1, 77.

53. Halbus, A.F.; Horozov, T.S.; Paunov, V.N.; ACS Appl. Nano Mater., 2020, 1,440 .

54. Millington, L.A.; Goulding, K.H.; Adams, N.; Water Res., 1988, 22 1593. 